\title{
Post-Earnings-Announcement Drift: The Role of Revenue Surprises and Earnings Persistence
}

\author{
Joshua Livnat \\ Department of Accounting \\ Stern School of Business Administration \\ New York University \\ 311 Tisch Hall \\ 40 W. $4^{\text {th }}$ St. \\ New York City, NY 10012
}

(212) 998-0022

jlivnat@stern.nyu.edu

First Draft: May 2003

Current Draft: June 12, 2003

The author gratefully acknowledges the contribution of Thomson Financial for providing forecast data available through the Institutional Brokers Estimate System. These data have been provided as part of a broad academic program to encourage earnings expectations research. The author also thanks Shai Levi, Suresh Radhakrishnan, and Dan Segal for their comments on an earlier version of this paper. 


\title{
Post-Earnings-Announcement Drift: The Role of Revenue Surprises and Earnings Persistence
}

\author{
$\underline{\text { Abstract }}$ \\ This study explores an additional factor that is associated with differential levels \\ of the post-earnings-announcement drift (henceforth drift)—-the contemporaneous \\ surprise in revenues. Consistent with prior evidence about greater persistence of revenues \\ and greater noise caused by heterogeneity of expenses, this study shows that the earnings \\ drift is stronger when the revenue surprise is in the same direction as the earnings \\ surprise. Moreover, the study provides direct evidence that the drift is stronger when the \\ earnings persistence is greater. The results are robust to various controls, including the \\ proportions of stock held by institutional investors, trading liquidity, and arbitrage risk.
}




\section{Post-Earnings-Announcement Drift: The Role of Revenue Surprises and Earnings Persistence}

One of the most puzzling market anomalies is the post-earnings-announcement drift (henceforth drift), where stock prices continue to move in the direction of the earnings surprise up to a year after the earnings is publicly known. ${ }^{1}$ The academic literature offers three major explanations for this phenomenon: (a) shifts in risks of firms with extreme surprises, justifying higher expected returns in equilibrium; (b) methodological problems in previous studies that document a phenomenon that does not exist in reality; and (c) investors' under-reaction to the earnings signal during the announcement period, which are subsequently corrected due to new information, delayed processing of the previously released information, or a combination of the two.

Recent research on the drift investigates factors that are associated with different drift levels according to prior intuition about the effects of these factors on investors' under-reaction. For example, Bartov et al. (2000) show that the drift is lower for companies with higher proportions of institutional investors, who are more sophisticated and less prone to under-reactions. Mikhail et al. (2003) provide evidence that the drift is smaller when companies are followed by more experienced analysts, who tend to incorporate the earnings surprise more fully in their forecasts and reduce the underreaction typically observed for less experienced analysts. Mendenhall (2003) shows that the drift is stronger for firms subject to higher arbitrage risks, consistent with a market

\footnotetext{
${ }^{1}$ A reversal typically occurs upon the announcement of same-quarter earnings in the following year.
} 
equilibrium of investors who initially under-react to earnings announcements and arbitragers who are unwilling to completely eliminate the under-reaction effects on prices due to greater arbitrage costs.

The purpose of this study is to investigate the role of revenue surprises in predicting differential drift levels, presumably due to the association of the revenue surprise with future earnings surprises. Ertimur et al. (2003) show that short-window market reactions to revenue surprises are stronger than those of expense surprises, because of the greater persistence of revenue surprises and the greater heterogeneity of expenses. ${ }^{2}$ Thus, when the sales surprise is in the same direction as the earnings surprise, the earnings surprise is more likely to persist in future periods, and a greater drift in prices is expected when investors obtain future information confirming the initial earnings surprise. In contrast, when the earnings surprise is mostly driven by an expense surprise (i.e., when the earnings and sales surprises are conflicting), the under-reaction may not manifest itself in a strong future drift, because future information is less likely to confirm the original earnings surprise. This study further examines the direct relationship between the drift and the earnings persistence.

The results show that the earnings drift is stronger when the earnings surprise is in the same direction as the sales surprise. These results continue to hold even after controlling for the sophistication of investors (the proportion of institutional holdings), trading liquidity, and arbitrage risk. The study also shows that the drift is stronger for earnings surprises of firms that have greater levels of earnings persistence. These results

\footnotetext{
${ }^{2}$ In their study, as in this study, the term "expenses" includes all items between sales and net income before extraordinary items, consisting of operating expenses, financial expenses, gains or losses on disposition of long-term assets, and non-recurring items.
} 
are robust in different sub-periods, including the most recent period (1998-2002), which spans extreme market increases and decreases. The results are also robust in three different samples: a large sample of firms with a wide dispersion of market capitalization, a sub-sample of firms that are followed by at least two analysts, and a much smaller subsample of firms that have at least one analyst forecast of revenues.

The evidence presented here has implications for academic research on the drift, highlighting factors that can systematically explain and predict differential drift levels according to firm-specific characteristics. It is also important for investors and market participants, who can use the evidence to improve their trading strategies when firms announce extreme earnings and revenue surprises. The documented results also have implications for fundamental analysis due to the differential effects of revenue and expense surprises on the persistence of earnings surprises.

The next section describes the prior literature and develops the hypotheses tested in this study. Section III describes the methodology and the samples. Section IV presents and discusses the results, and last section provides a summary and conclusions.

\section{Prior Research and Motivation}

Prior studies, beginning with Ball and Brown (1968), followed by Foster et al. (1984) and Bernard and Thomas $(1989,1990)$ document the existence of a post-earningsannouncement drift in stock returns. In particular, stock returns do not impound the surprise in announced earnings immediately upon the earnings disclosure; stock returns are associated with the surprise in earnings for up to a year afterwards, although most of 
the drift occurs around subsequent earnings announcements. ${ }^{3}$ In his review of the drift literature, Kothari (2001) argues that the drift provides a serious challenge to the efficient markets hypothesis because it has survived rigorous testing for over 30 years and cannot be fully explained by other documented anomalies.

Recent studies of the drift convincingly demonstrate that the drift's strength is different for different subsets of firms in predictable and intuitively logical ways. For example, Bartov et al. (2000) show that the drift is smaller for firms with greater proportions of institutional investors, likely because institutional investors are more sophisticated and less liable to rely on the too-simplistic seasonal random walk model of earnings. Similarly, Mikhail et al. (2003) find that the drift is smaller for firms that are followed by experienced analysts, who tend to employ more sophisticated prediction models for earnings than just a seasonal random walk. Mendenhall (2003) shows that firms subject to lower arbitrage risks have smaller drifts, because arbitragers can exploit arbitrage opportunities created at lower arbitrage costs. Brown and Han (2000) find that for a selected sample of firms whose earnings generating process can be described by a simple AR1 model, there is a smaller drift for large firms than for small firms with a poorer information environment (measured by size, institutional holdings, and number of analysts following the firm). Thus, recent research efforts have been directed toward understanding the factors that are associated with differential drift levels.

\footnotetext{
${ }^{3}$ For other drift-related studies see, e.g., Bartov (1992), Ball and Bartov (1996), and Bartov et al. (2000). See Abarbanell and Bernard (1992) on the relationship of the drift to analysts' forecasts. Evidence that analysts may not fully incorporate past information into their forecasts is available in Lys and Sohn (1990), Klein (1990), Abarbanell (1991), and Mendenhall (1991).
} 
The above studies relate mostly to the firm's external environment: its stockholders, its arbitrage risk, analysts' experience, and the information environment. ${ }^{4}$ In contrast, differential drift levels may also be related to the inherent persistence of earnings. For a drift to exist, market participants must realize after the initial earnings announcement that their immediate reaction to the earnings surprise was insufficient. This is likely to occur, for example, if new information confirms the prior earnings surprise, such as a subsequent earnings release. Indeed, Shane and Brous (2001) show that market returns after the release of earnings are consistent with investors and analysts incorporating new information about the firm in correcting their under-reactions to the initial earnings signal. When the initial earnings surprise is expected to persist, the drift is likely to be larger than when the initial earnings surprise is less likely to persist, because subsequent confirmatory signals are more likely to occur than conflicting signals. Thus, another approach to identify cases of a larger drift using firm-specific characteristics is to focus on factors that are related to the persistence of earnings surprises. This study explores the interaction of a contemporaneous revenue surprise with the earnings drift.

To understand the role of contemporaneous revenues in assessing the persistence of earnings surprises, this study relies on prior evidence about the differential properties of revenues and expenses. Ertimur et al. (2003) show that revenue surprises are more persistent than expense surprises in a large sample of quarterly earnings announcements. If revenue surprises are more likely to persist than expense surprises, then the observation of an extreme earnings surprise accompanied by a revenue surprise in the same direction is indicative of a greater probability of future information confirming the current earnings

\footnotetext{
${ }^{4}$ It can be argued that these factors are related to firm-specific characteristics through self-selection. For example, institutional stockholders may be attracted to firms with more stable operations or high growth.
} 
surprise, and it is more likely to be associated with a stronger drift than an extreme earnings surprise that is driven mostly by a less persistent expense surprise. Furthermore, Ertimur et al. (2003) show that the heterogeneity of expenses may also negatively affect the interpretation of earnings surprises. For example, an extreme earnings surprise may be caused by non-recurring expenses such as restructuring expenses or gains/losses on the sale of fixed assets. The extreme expenses may also be caused by unusually high (low) levels of expenses that constitute investments, such as advertising expenses, which are likely to be associated with higher (lower) future earnings (i.e., resulting in a lower persistence of the earnings surprise). Thus, the persistence of an extreme earnings surprise is likely to be lower when the earnings surprise is driven by an expense surprise rather than a revenue surprise, and the subsequent drift in returns is likely to be lower. This leads to the first hypothesis (posited in the alternative form):

$\mathrm{H}_{1}$ : The abnormal returns observed in the period after the earnings (and revenue) announcements are positively and significantly associated with the surprise in revenues, after controlling for the surprise in earnings.

To the extent that under-reactions to earnings surprises are caused by investors who seek additional information, it may be expected that firms with higher levels of earnings persistence will have greater levels of drift. This will occur because, for such firms, the observation of an extreme earnings surprise is more likely to be followed by another earnings surprise in the same direction, implying a higher probability of future news that confirms the original earnings surprise. Thus, we can test the direct relationship 
between earnings persistence and the drift. This leads to the second hypothesis (stated in the alternative form):

$\mathrm{H}_{2}$ : Firms with greater persistence of earnings surprises have greater drift levels.

Note that the factors examined in this study are not related to the firm's environment (which for the most part is exogenous to the firm), but to firm-specific characteristics, such as the persistence of earnings surprises and the relationship between revenue and expense surprises. Thus, they broaden our understanding of potential causes of the drift beyond investigating factors that are related to the firm's micro-structure. The methodology to test these hypotheses is described in the next section.

\section{Methodology and Sample}

\section{Estimation of the earnings surprise (SUE):}

Most prior studies of the drift used the historical SUE as the basis for classifying firms into sub-groups according to their earnings surprise. The typical approach is to estimate expected earnings from a rolling seasonal random walk with a drift model. The SUE is defined as actual earnings minus expected earnings, scaled by the standard deviation of forecast errors during the estimation period. This study uses the same methodology as Bartov et al. (2000) and Bartov (1992). For each quarter $t$ and firm $j$, the following model is first estimated:

$$
\mathrm{X}_{\mathrm{jt}}=\delta_{\mathrm{jt}}+\mathrm{X}_{\mathrm{jt}-4}+\varepsilon_{\mathrm{jt}},
$$


where $\mathrm{X}$ is earnings (Compustat quarterly item 8 , income before extraordinary items) or sales (Compustat quarterly item 2$), \delta_{\mathrm{jt}}$ is the estimated drift, and $\varepsilon_{\mathrm{jt}}$ a serially independent, equal-variance random noise. This model is estimated using quarters $\mathrm{t}-21$ through $\mathrm{t}-1$. The standard deviation of the forecast errors from (1) is estimated during the same period and is denoted as $\mathrm{STD}_{\mathrm{jt}}$. The definition of SUE is

$$
S U E_{j t}=\frac{\left(X_{j t}-\delta_{j t}-X_{j t-4}\right)^{\cdot}}{S T D_{j t}}
$$

The main advantage of using the historical definition of SUE in (2) is that it can be estimated for any firm in the Compustat database, regardless of its size or analyst following. The only requirement is for the firm to have sufficient prior earnings (sales) observations to estimate (1). However, there are a few problems with this approach. Unlike the Compustat annual database, which is not restated to reflect subsequent corrections made by the firm to the previously reported original data, the Compustat quarterly database is continuously restated to reflect such new information. Thus, using the historical SUE to estimate the earnings surprise may introduce a bias when the information is subsequently restated due to such events as mergers, acquisitions, divestitures, corrections of errors, etc. The researcher may estimate a surprise that was not actually available to market participants at the time of its disclosure. A further problem with the historical SUE is that reported earnings may be affected by special items that investors and analysts have not included in their predictions. Note that both of these problems are likely to cause stronger biases in the extreme SUE deciles, where most of the drift occurs. 
Mendenhall (2003) provides an alternative approach to estimate SUE, where the surprise is based on actual earnings minus the mean analyst forecast of earnings, scaled by the dispersion of analyst forecasts. The main advantage of this approach is that it is based on actual earnings as reported by the firm originally, not including any subsequent restatements of the original data, and adjusted for special items. Note that this approach does not require a long history of earnings and is suitable for young firms as well. The main problem of this approach is that it is limited to firms that are followed by analysts, introducing a potentially significant sample-selection bias. A further problem with this approach for the current study is that sales forecasts by analysts have been collected by I/B/E/S only since 1997 (a few are available in 1996), and even then not by all brokers and not for all firms for which earnings forecasts are available. To mitigate the concerns of the historical SUE from Compustat, this study also uses analyst forecasts to estimate SUE.

Similar to Mendenhall (2003), for each quarter $t$ and firm $j$, all quarterly forecasts made by analysts during the 90-day period before the disclosure of actual earnings constitute the non-stale, relevant forecast group. ${ }^{5}$ The earnings SUE is defined as actual earnings per share (EPS) from I/B/E/S minus the mean analyst forecast of EPS in the group, scaled by the standard deviation of forecasts included in the group. Like Mendenhall (2003), firm-quarters with fewer than two forecasts in the group are deleted, and the standard deviation of EPS is set to 0.01 if it is equal to zero.

Since analyst sales forecasts in I/B/E/S are available for fewer firms, and even then many firm-quarters have only one available analyst forecast in the 90-day period before the disclosure of earnings, the sales surprise is defined differently. It is defined as 
actual sales from $\mathrm{I} / \mathrm{B} / \mathrm{E} / \mathrm{S}$ minus the mean analyst forecast of sales in the group, scaled by actual sales from I/B/E/S. The analyst forecast sales SUS (Standardized Unexpected Sales) is calculated even if only one analyst forecast of sales is available in the $\mathrm{I} / \mathrm{B} / \mathrm{E} / \mathrm{S}$ database.

\section{Sample Selection:}

The analysis in this study is performed on three samples of firms, using different definitions of SUE (SUS) depending on the sample. The first sample uses historical SUE and SUS and is estimated from Compustat for all firms with available data. The second sample estimates earnings SUE using analyst forecasts of EPS but uses the historical Compustat database to estimate the sales SUS. This sample is smaller than the first, because it is restricted to companies that are followed by at least two analysts in the 90day period before the disclosure of actual earnings, but it has the advantage of using the originally disclosed EPS (after I/B/E/S's own adjustments for special items). Finally, the third sample includes both SUE and SUS that are estimated from analyst forecasts and is therefore restricted to the post-1996 period and to fewer firms.

Other selection criteria used in this study for each quarter $t$ are as follows:

1. The date on which earnings are announced to the public is reported in Compustat for both quarter $t$ and quarter $t+1$ (returns are cumulated through the next earnings announcement date).

2. The number of shares outstanding and the price per share are available from Compustat as of the end of quarter $\mathrm{t}-1$. These are used to calculate the market value of equity as of quarter $\mathrm{t}-1$.

\footnotetext{
${ }^{5}$ This group includes only the most recent forecast made by a specific analyst within this period.
} 
3. The book value of equity at the end of quarter $\mathrm{t}-1$ is available from Compustat and is positive.

4. The firm's shares are traded on the NYSE, AMEX, or NASDAQ.

5. Daily returns are available in CRSP from one day after quarter t's earnings announcement through the announcement date of earnings for quarter $\mathrm{t}+1$.

6. Data are available to assign the firm into one of the six Fama-French portfolios based on size and $\mathrm{B} / \mathrm{M}$.

7. Both sales SUS and earnings SUE can be calculated for the quarter.

\section{Assignment to SUE and SUS Deciles:}

Because the SUE and SUS have distributions with extreme observations at the tails, most drift studies classify firms into 10 portfolios sorted according to their SUE, and the analysis is performed on the portfolio rank, where the ranks are scaled to fall between 0 and 1 . The interpretation of the slope coefficient in the regression of abnormal returns on the SUE decile rank is equivalent to a return on a hedge portfolio that holds the most positive SUE decile long and shorts the most negative SUE decile.

Most researchers rely on Bernard and Thomas (1990), who report that the drift is insensitive to the assignment of firms into a SUE decile using the current quarter's SUE values, instead of using SUE cutoffs from quarter t-1. To reduce this potential look-ahead bias, which assumes that the entire cross-sectional distribution of SUE is known when a firm announces its earnings for quarter $t$, this study uses SUE and SUS cutoffs from quarter $\mathrm{t}-1$ for all three samples. This study further assigns a firm into a quarter $\mathrm{t}$ based on calendar quarters, instead of fiscal quarters, to ensure communality of economic 
conditions. Thus, a firm-quarter is assigned to calendar quarter $t$ if the month of the fiscal quarter's end falls within one month of the calendar quarter's end. For example, the first calendar quarter of 1999 will include all firm-quarters with a fiscal quarter-end of February 1999, March 1999, and April 1999.

\section{Cumulative Abnormal Returns (CAR):}

The daily abnormal return is calculated as the raw daily return from CRSP minus the daily return on the portfolio of firms with the same size (the market value of equity as of June) and book-to-market (B/M) ratio (as of December). The daily returns (and cut-off points) on the size and B/M portfolios are obtained from Professor Kenneth French's data library, based on classification of the population into six (two size and three $\mathrm{B} / \mathrm{M}$ ) portfolios. ${ }^{6}$ The daily abnormal returns are summed over the period from one day after the earnings announcement date through the day of the following quarterly earnings announcement. Consistent with prior studies, the top and bottom $0.5 \%$ of the CARs are deleted from the sample.

\section{Institutional Holdings:}

Consistent with Bartov et al. (2000), regression results in this study are controlled for the potential effects of institutional holdings. The first step is to aggregate the number of shares held by all managers at the end of quarter $\mathrm{t}-1$, as reported on all $13-\mathrm{f}$ filings made for firms $j$, which are included in the Thomson Financial database maintained by WRDS. This number of shares is divided by the number of shares outstanding at the end of quarter $\mathrm{t}-1$ for firm $\mathrm{j}$ to obtain the proportion of outstanding shares held by sophisticated investors. Consistent with Bartov et al. (2000), firms are ranked according to the proportion of institutional holdings and are assigned to 10 groups. The decile rank 
is the variable used in this study. It is expected that the drift should be smaller for firms with a larger proportion of institutional holders; i.e., a negative association is expected between CAR and the proportion of institutional holdings.

\section{Arbitrage Risk:}

Consistent with Mendenhall (2003), arbitrage risk is estimated as one minus the squared correlation between the monthly return on firm $\mathrm{j}$ and the monthly return on the S\&P 500 Index, both obtained from CRSP. The correlation is estimated over the 60 months ending one month before the calendar quarter-end. The arbitrage risk is the percentage of return variance that cannot be attributed to (or hedged by) fluctuations in the S\&P 500 return. Mendenhall (2003) shows that the drift is smaller when the arbitrage risk is smaller, so a positive association is expected between CAR and the arbitrage risk.

\section{Trading Volume:}

Trading volume has been used by prior studies of the drift as a control in the association between the CAR and SUE. It is expected that a higher trading volume may reduce the costs of arbitrage and therefore is expected to have a negative association with CAR. To estimate trading volume, the average monthly trading volume is obtained from CRSP for the same period as that used to estimate the arbitrage risk. The average monthly trading volume is then divided by the total shares outstanding at the end of quarter $\mathrm{t}-1$.

\section{$\underline{\text { Statistical Tests: }}$}

Most of the prior drift studies rely primarily on regression analysis, where the dependent variable is the cumulative abnormal return (CAR) and the independent variables are the SUE decile rank, DSUE, and other control variables. Since most of the

\footnotetext{
${ }^{6} \mathrm{http}: / /$ mba.tuck.dartmouth.edu/pages/faculty/ken.french/data_library.html.
} 
subsequent drift in returns occurs for extreme SUE surprises, the control variables are typically interacted with the SUE decile rank, DSUE. This is reasonable when the implicit assumption (intuition) is that the higher the level of the earnings surprise the greater will be the effect of the control variable. For example, when the earnings surprise is extreme, the greater the proportion of institutional investors, the smaller the drift level. For minor earnings surprises, the proportion of institutional investors will likely have no (or a minor) effect on the drift, because the initial under-reaction is likely to be insignificant.

Similar to prior studies, the effect of the sales surprise is added into the regression equation as an interaction with the earnings surprise. The intuition for the interactive term is that for minor earnings surprises the subsequent drift in prices is likely to be small regardless of the sales surprise, because investors are unlikely to seek additional information to help interpret the minor earnings surprise. In contrast, when the earnings surprise is large, investors seek additional information, and the more the sales surprise goes in the same direction as the earnings surprise, the more likely it is that future news will confirm the initial announcement, resulting in a larger drift. Thus, the partial derivative of the drift with respect to the sales surprise is an increasing function of the earnings surprise, implying an interaction term in the regression. To assess the significance of regression coefficients, this study uses a pooled time-series crosssectional regression, as well as average coefficients from quarterly regressions in a methodology similar to that of Fama and MacBeth (1973).

Another approach for testing the incremental effect of the sales surprise beyond the earnings surprise is based on the additional returns that a hedge portfolio can earn. 
Consider first an earnings hedge portfolio that consists of long positions in all firms with a SUE decile rank of $8-10$ (the top 30\% of SUE) and short positions in the bottom $30 \%$ of the SUE distribution. This hedge portfolio is reconstituted every quarter, depending on the quarterly SUE. An alternative hedge portfolio is a subset of the above portfolio, where the short positions are of firms with both earnings (SUE) and sales (SUS) surprises in the bottom $30 \%$ of the distribution, and long positions in firms with both earnings and sales surprises at the top $30 \%$ of their distributions. This portfolio is also reconstituted every quarter. The mean difference in returns between these two portfolios over all available quarters can be used to test the incremental returns due to utilization of the sales surprise in addition to the earnings surprise. To the extent that the sales surprise helps in identifying firms that have more persistent earnings surprises with future confirmatory news, the drift for such firms will be significantly larger than for all firms with a SUE in the top or bottom $30 \%$ of the distribution.

\section{Sample Period:}

The sample based on historical SUEs begins in the second quarter of 1987 with 1,739 firms and reaches 3,557 firms in the third quarter of 2002. The sample that uses earnings SUE based on analyst forecasts of EPS and sales SUS based on historical data begins in the second quarter of 1989 with 731 firms and reaches 1,526 firms in the third quarter of 2002. Finally, the sample that uses analyst forecasts to estimate the surprise in both earnings and sales begins with 175 firms in the third quarter of 1998 and reaches 1,116 firms in the third quarter of 2002.

Table 1 provides summary statistics about the three samples. As can be seen in all three panels of the table, the mean earnings SUE is negative, although the median 
earnings surprise is positive and equals about $3-4 \%$ of the standard deviation of earnings surprises in the preceding 20 quarters. These results are similar to those reported in Bartov et al. (2000). In contrast, the mean sales SUS is positive, as is the median when estimated from historical data (Panels A and B), but the median is negative when estimated from analyst forecasts of sales (Panel C). Both the earnings and sales SUE (SUS) exhibit wide distribution with extreme values; hence the need to transform the SUE (SUS) into its decile rank for the following analysis.

(Insert Table 1 about here)

The mean percentage of shares held by institutions is $36 \%$ for our historical SUE sample, compared with the $41 \%$ reported by Bartov et al. (2000), who use only NYSE and AMEX firms; the current study uses NASDAQ firms, too. Note that the mean proportion of institutional holdings is much higher in Panels B and C of Table 1. This is expected because analysts tend to write research reports about firms that are of more interest to institutional holders. The mean arbitrage risk reported in Table 1 is around $86 \%$, which implies that the mean $\mathrm{R}^{2}$ of regressing the stock return on the S\&P 500 Index is about $14 \%$, consistent with results reported in prior studies. The average monthly trading volume as a proportion of shares outstanding is about $6.6 \%$ for the historical SUE sample, and slightly higher for the analyst forecast samples, as can be expected. It is also evident from the table that the historical SUE sample has a wide distribution of firms in terms of size (market value of equity at the end of the previous quarter), and that the subset of firms that are followed by analysts have larger market values. The narrower subset of firms for which analysts provide sales forecasts (Panel C) has even larger market values. Finally, the mean CAR is small and negative at $-0.4 \%$ and $-0.7 \%$ in 
Panels A and B, respectively, but positive (0.8\%) in Panel C, possibly due to the specific time period covered in this last sample (1998-2002).

\section{Results}

Table 2 provides the results of regressing CAR on the earnings decile SUE rank, DSUE; on both the earnings decile rank DSUE and its interaction with the sales decile rank, DSUS; as well as on these two variables along with control variables for institutional holdings, arbitrage risk, and trading volume. Consistent with prior studies, the control variables are interacted with the earnings surprise. These regressions are repeated for the three samples identified above, but for brevity, only the results of the historical earnings and sales surprises from Compustat and those from analyst forecasts are reported in the tables. In addition to the standard pooled regression results, the tables report results that are based on separate quarter-by-quarter regressions that are summarized using a Fama and MacBeth (F-M) (1973) methodology. Due to the smaller number of quarters for the analyst forecast (of sales) sample (1998-2002), the F-M results for this sample should be interpreted with caution. Note that the number of observations is different in the results of the regression with the control variables because of observations missing data on any of the control variables.

(Insert Table 2 about here)

As can be seen in Panel A of Table 2, for the sample that is based on SUE calculated from the data in the Compustat database, the coefficient on the earnings decile 
SUE rank (DSUE) has the predicted positive sign and is statistically different from zero. It is also similar in magnitude to that reported by Bartov et al. (2000). When the sales decile SUE rank is added into the regression as an interactive term with earnings, the earnings DSUE is reduced by about $1.5 \%-1.8 \%$, but the coefficient on the interaction with the sales decile rank, DSUS, is also positive, significantly different from zero, and roughly equal to $2.4 \%-2.9 \%$. This magnitude implies that trading based on shorting the smallest sales surprises and holding long the largest sales surprises, after controlling for the effects of the earnings SUE decile rank, can improve the abnormal return during the subsequent quarter by about $1 \%$, or about $4 \%$ annually. This is an economically meaningful increase in abnormal returns beyond those that can be earned by using the earnings SUE alone. The same conclusions are obtained after controlling for the proportion of stock held by institutions (negatively associated with the drift, as expected), arbitrage risk (positively associated with the drift, as expected), and trading volume (negatively associated with the drift, as expected). Thus, the previously documented earnings drift can be enhanced if the sales decile SUE rank is used to further select firms into the hedge earnings SUE portfolio.

Panel B provides the results of these regressions for the sample of firms with analyst forecasts of both earnings and sales. The earnings surprise DSUE has a coefficient with a magnitude similar to that based on historical DSUE from Compustat when this is the only independent variable in the regression. This evidence indicates that the drift exists in recent periods, too, since this sample contains observations from 1998 onward. Further evidence on the historical SUE and SUS effects in various sub-periods is provided below. Panel B also shows that when the interaction with the sales surprise 
DSUS is added into the regression, the earnings surprise (DSUE) loses significance, and the interaction with the sales surprise (DSUS) is larger in magnitude and significantly different from zero. The significance of the interaction with the sales surprise continues to hold even after controlling for institutional holdings, arbitrage risk, and trading volume, all of which are now insignificantly different from zero. ${ }^{7}$ Thus, the results in Table 2 reject $\mathrm{H}_{1}$ and support the role of the sales surprise in interpreting the extreme earnings surprises.

Table 3 presents the mean CAR, the number of observations, and the associated significance level of the CAR for a $3 \times 3$ table of firms classified according to DSUE and DSUS, where the classifications according to DSUE and DSUS are independent of each other. Firms are assigned to three groups based on their earnings and sales surprises, with the bottom $30 \%$ in one group, the next $40 \%$ in another, and the last consisting of the top $30 \%$. It is expected that the bottom $30 \%$ will have a negative drift (CAR), the top $30 \%$ a positive drift, and the middle $40 \%$ a small drift. As can be seen in Panel A of Table 3, the bottom $30 \%$ of DSUE has a mean drift of $-2.30 \%$ through the next earnings announcement, the middle $40 \%$ a mean drift of $-0.49 \%$, and the top $30 \%$ a mean drift of $1.64 \%$. In contrast, the bottom $30 \%$ of the sales surprise (DSUS) has a mean drift of $1.50 \%$, the middle $40 \%$ a mean drift of $-0.37 \%$, and the top $30 \%$ a mean drift of $0.67 \%$. Thus, the spread in the earnings-based drift seems to be larger than the spread in the sales-based drift.

\footnotetext{
${ }^{7}$ Untabulated results for the sample with earnings SUE based on analyst forecasts and sales SUS based on historical data indicate that the interactive sales surprise DSUS has a positive and significant coefficient in the pooled regression, even after controlling for the effects of institutional holdings, arbitrage risk, and trading volume. This coefficient is positive but not significant in the Fama and MacBeth regressions, perhaps because of the added noise in the individual quarterly regressions.
} 
(Insert Table 3 about here)

Further examination of Panel A in Table 3 shows that there are more firms in groups along the diagonal than outside the diagonal. This is expected, because the DSUE and DSUS are determined independently, and firms with an extreme earnings surprise are also more likely to have a sales surprise in the same direction. Note, however, that the sales surprise can help in identifying the future earnings drift. For example, for the bottom $30 \%$ of earnings surprises, the mean drift is $-2.30 \%$, but it is only $-2.01 \%$ for those $(7,892)$ observations in the top $30 \%$ of sales surprises. Similarly, although the average drift is $1.64 \%$ for the top $30 \%$ of earnings surprises, it is only $0.57 \%$ for the $(7,903)$ observations in the bottom $30 \%$ of sales surprises, but $2.07 \%$ for those observations in the top $30 \%$ of sales surprises as well. A similar picture, albeit more extreme, is observed in Panel B of Table 3, which contains data about the sub-sample of firms that had both earnings and sales forecasts by analysts. In this group, the mean drift of the group with earnings and sales surprises is $4.48 \%$, in comparison with a mean drift of only $-1.67 \%$ for firms with earnings and sales surprises in the bottom $30 \%$. This is comforting, because it is much easier in practice to obtain returns on long positions than on short positions; i.e., if most of the drift is derived from short positions, it is more questionable that such an investment strategy can actually be implemented in practice. ${ }^{8}$

The results in Table 3 are economically significant because the table presents mean quarterly returns. Annual returns on the combined SUE and SUS hedge portfolio

\footnotetext{
${ }^{8}$ A similar picture emerges for the sub-sample with analyst forecasts of earnings but sales SUS based on historical data. The group of firms in the top 30\% of both SUE and SUS has a mean quarterly return of $2.53 \%$, as compared to $1.95 \%$ for all firms in the top 30\% of SUE group. However, firms in the bottom $30 \%$ of both SUE and SUS did not have a higher mean return than those in the bottom $30 \%$ of SUE.
} 
can be very significant, $2.07 \%+2.38 \%$ per quarter in Panel A, or about $19 \%$ annually, and $4.48 \%+1.67 \%$ per quarter in Panel B, or about $27 \%$ annually. These are mean returns across quarters, and given the risk of the strategy, an actual application of the hedge portfolio should also consider the variability of these returns across quarters. To address this, Table 4 provides information about the average quarterly returns on the earningsbased hedge portfolio, the average quarterly returns on the earnings- and sales-based hedge portfolio, their standard deviations, their associated t-statistics, and their significance levels. The earnings (earnings and sales) strategy is based on holding short positions in the bottom $30 \%$ of the SUE (SUE and SUS) and long positions in the top $30 \%$ of SUE (SUE and SUS), where positions are closed each quarter.

\section{(Insert Table 4 around here)}

As can be seen in Panel A of Table 4, based on the 63 observed quarters, the mean earnings-based hedge portfolio yields an average quarterly drift of $1.944 \%$, with an associated significance level of 0.001 . However, the earnings- and sales-based hedge portfolio yields a higher return, 2.210\% quarterly, also significantly different from zero, and the difference between this portfolio return and the return on the earnings-based hedged portfolio is about $0.27 \%$ per quarter, which is significantly different from zero at a 0.025 significance level. Panel B, for SUE and SUS based on analyst forecasts and only 17 quarters, shows an even larger difference; a $2.199 \%$ return on the earnings-based portfolio and a $3.620 \%$ return on the earnings and sales hedge portfolio, with a mean difference of $1.421 \%$ per quarter, which is statistically different from zero at a 0.04 significance level. Note that the significant improvement in the performance of the earnings and sales hedge portfolio over the earnings hedge portfolio comes at a cost - this 
portfolio has substantially fewer firms on average than the earnings-based hedge portfolio: 786 firms as compared to 1,586 firms in Panel A, and 122 vs. 302 in Panel B. Thus, the improvement in the performance of the earnings and sales hedge portfolio comes from an elimination of firms with conflicting earnings and sales signals, which tend to reduce the drift for the earnings-based hedge portfolio, likely because of later news that conflict with the original earnings surprise. ${ }^{9}$

Table 5 reports regression results similar to those in Table 2 for three sub-periods: observations during the years 1987-1992, 1993-1997, and 1998-2002. The sample observations are all based on SUE estimated from Compustat using the seasonal random walk model for both earnings and sales. The earnings drift is present and significant in all three sub-periods; there is no indication in the table that the earnings SUE effect is reduced in the most recent period. Notice that the period 1998-2002 includes periods of both severe market increases and decreases. The incremental sales SUS effect is present and statistically different from zero in all three sub-periods. It does seem to contribute slightly less after 1998 , only about $1.8 \%$ per quarter beyond the earnings SUE effect; this is still an economically significant additional return. The results for the earnings and sales SUE are present in all three sub-periods after controlling for institutional holdings, arbitrage risk, and trading volume. Thus, the documented results of this study are not driven by any sub-period, and they are consistent in different market conditions,

\footnotetext{
${ }^{9}$ For the sub-sample with analyst forecasts of earnings but sales SUS based on historical data, the hedge portfolio based on earnings and sales yields an average quarterly return of about $0.25 \%$ larger than the return on the hedge portfolio that is based only on earnings. However, due to a greater variance of these differences across quarters, this difference is significantly different from zero, with a significance level of 0.187 .
} 
including market increases, declines, and periods that span both. They are also consistent for both earnings and sales surprises based on historical estimates and analyst forecasts.

(Insert Table 5 about here)

\section{The Effects of Persistence:}

The prior analysis showed that the sales surprise can be used to further interpret the earnings surprise in predicting the drift's direction and strength. These results likely arise from the greater persistence of the sales surprise and the relative homogeneity of sales as compared to expenses. To provide additional evidence about the role of earnings persistence, this sub-section focuses on the direct relationship between the earnings persistence and drift.

As a first step, the persistence of earnings and sales surprises is estimated by using all available quarterly observations for each firm in the sample. The persistence of earnings (sales) surprise is estimated by the first auto-correlation of SUE (SUS), as long as the firm has at least nine observations. To compare the magnitude of the persistence of earnings and surprises, the sample consists of all firms with both persistence measures as of the third quarter of 2002. This quarter is selected for analysis due to the sharp decline in the number of firms during the fourth quarter of 2002 because of missing data at the time of this study. There are 3,220 firms with persistence measures for both earnings and sales surprises. The mean earnings persistence is 0.249 , the mean sales persistence is 0.548 , and the difference is statistically different from zero at a 0.001 level of significance. The distribution of the mean difference in persistence (sales minus earnings) 
is $-0.107(10 \%), 0.083(25 \%), 0.293$ (median), $0.528(75 \%)$, and $0.713(90 \%)$. Thus, the persistence of sales in our sample of firms is greater than the persistence of earnings.

Table 6 presents regression results similar to those in Table 2, except that instead of an interactive term with the sales surprise the table provides an interactive term of DSUE with persistence. As can be seen in the table, persistence is positively associated with the drift in returns subsequent to the announcement, and its coefficient is statistically different from zero, even after controlling for institutional holdings, arbitrage risk, and trading volume. These results are consistent with $\mathrm{H}_{2}$, indicating the importance of earnings persistence to the drift. Presumably, other variables that are associated with earnings persistence can also help predict the drift, as we saw earlier for the earnings persistence. ${ }^{10}$

\section{Sensitivity Analysis:}

1. The regression results in Panel A of Table 2 are repeated for companies with market values in excess of $\$ 100$ million at the previous quarter's end, to assess the effect of removing smaller companies with poorer information and trading environments. The incremental sales SUS drift is still positive and significantly different from zero. The control variable of institutional investors becomes positive and significant, and the arbitrage risk becomes insignificant.

2. The regression results in Panel A of Table 2 are repeated for companies traded on the NYSE and AMEX, to assess the effect of removing smaller companies with

\footnotetext{
${ }^{10}$ The persistence results contain a look-ahead bias; persistence is estimated using all quarters for a specific firm. The purpose is to show the relationship of persistence to the drift and not to devise a trading rule.
} 
poorer information and trading environments. The incremental sales SUE drift is still positive and significantly different from zero. The control variable of institutional investors becomes positive and significant.

3. The results of the study are qualitatively similar for a sub-sample of firms with more than one analyst forecast of sales, although significance levels decline somewhat.

\section{Summary and Conclusions}

This study shows that the magnitude of the observed drift in security returns after the disclosure of earnings is dependent on the sales surprise disclosed simultaneously with earnings. When the two signals confirm each other, the magnitude of the drift is larger, probably because revenues are more persistent and expenses more heterogeneous. Similarly, this study shows that the drift is positively and significantly related to earnings persistence.

The combined evidence in this study has implications for academics and practitioners. Research efforts to understand and investigate the drift, its causes, and its effects should take into account such characteristics as the persistence of earnings, the separate sales and expense surprises, and other variables that can affect earnings persistence. Practitioners who base their portfolio decisions (among other things) on the earnings surprise should take into account the sales surprise as well and consider whether it confirms the earnings surprise. These factors may affect future returns. 
Finally, fundamental security analysis in academe and practice may have to incorporate detailed analysis of a firm's prior persistence of revenues and expenses to assess their potential effects on security prices. 


\section{References}

Abarbanell, J., 1991. Do analysts' earnings forecasts incorporate information in prior stock price changes? Journal of Accounting and Economics 14, 147-165.

Abarbanell, J., Bernard, V., 1992. Tests of analysts' overreaction/underreaction to earnings information as an explanation for anomalous stock price behavior. Journal of Finance 47, 1181-1207.

Ball, R. and Brown, P., 1968. An empirical evaluation of accounting income numbers. Journal of Accounting Research 6, pp. 159-177.

Ball, R., and Bartov, E., 1996. How naïve is the stock market's use of earnings information? Journal of Accounting and Economics 21, 319-337.

Bartov, E., 1992. Patterns in unexpected earnings as an explanation for postannouncement drift. The Accounting Review 67, 610-622.

Bartov, E., Radhakrishnan, S., Krinsky, I., 2000. Investor sophistication and patterns in stock returns after earnings announcements. The Accounting Review 75, 43-63.

Bernard, V., Thomas, J., 1989. Post-earnings-announcement drift: delayed price response or risk premium? Journal of Accounting Research 27, 1-48.

Bernard, V., Thomas, J., 1990. Evidence that stock prices do not fully reflect the implications of current earnings for future earnings. Journal of Accounting and Economics 13, 305-340.

Brown, L. and Han, J., 2000. Do stock prices fully reflect the implications of current earnings for future earnings for AR1 firms?. Journal of Accounting Research 38, pp. 149-164.

Ertimur, Y., J. Livnat and M. Martikainen, 2003, Differential Market Reactions to Revenue and Expense Surprises, Forthcoming, Review of Accounting Studies.

Fama, E. F. and James D. MacBeth, 1973 Risk, return, and equilibrium: Empirical tests, Journal of Political Economy, 81, 607-636.

Foster, G., Olsen, C., Shevlin, T., 1984. Earnings releases, anomalies and the behavior of security returns. The Accounting Review 59, 574-603.

Klein, A., 1990. A direct test of the cognitive bias theory of share price reversals. Journal of Accounting and Economics 13, 155-166.

Kothari, S.P., 2001. Capital markets research in accounting, Journal of Accounting and Economics 31, 105-231. 
Lys, T., Sohn, S., 1990. The association between revisions of financial analysts' earnings forecasts and security price changes. Journal of Accounting and Economics 13, 341-363.

Mendenhall, R., 1991. Evidence on the possible under-weighting of earnings-related information. Journal of Accounting Research 29, 170-179.

Mendenhall, R., 2003. Arbitrage Risk and Post-Earnings-Announcement Drift, Journal of Business, Forthcoming.

Mikhail, Michael B., Beverly R. Walther and Richard H. Willis, 2003, The effects of experience on security analyst underreaction, Journal of Accounting and Economics 35, 101-116.

Shane, Philip, and Peter Brous, 2001, "Investor and (Value Line) Analyst Undereaction to Information about Future Earnings: The Corrective Role of Non-EarningsSurprise Information, Journal of Accounting Research 39:2 (September), 387404. 


\section{Table 1 \\ Summary Statistics}

\begin{tabular}{|l|r|r|r|r|r|r|r|r|}
\hline \multicolumn{1}{|l|}{ Panel A: Historical SUE } \\
\hline Variable & $\mathbf{N}$ & Mean & $\begin{array}{r}\text { Std } \\
\text { Dev }\end{array}$ & $\begin{array}{r}\text { 10th } \\
\text { Pctl }\end{array}$ & $\begin{array}{r}\text { 25tht } \\
\text { Pctl }\end{array}$ & $\begin{array}{r}\text { 50tht } \\
\text { Pctl }\end{array}$ & $\begin{array}{r}\text { 75th } \\
\text { Pctl }\end{array}$ & $\begin{array}{r}\text { 90th } \\
\text { Pctl }\end{array}$ \\
\hline Earnings SUE & 164401 & -0.185 & 17.607 & -1.771 & -0.596 & 0.041 & 0.643 & 1.614 \\
\hline Sales SUS & 164401 & 0.153 & 1.933 & -1.672 & -0.788 & 0.068 & 0.970 & 2.006 \\
\hline Proportion of Institutional Holdings & 160878 & 0.359 & 0.243 & 0.048 & 0.146 & 0.336 & 0.551 & 0.704 \\
\hline Arbitrage Risk & 145131 & 0.864 & 0.135 & 0.665 & 0.798 & 0.907 & 0.970 & 0.994 \\
\hline $\begin{array}{l}\text { Average Trading Volume (\% of Outstanding } \\
\text { Shares) }\end{array}$ & 145131 & 0.066 & 0.069 & 0.014 & 0.025 & 0.045 & 0.082 & 0.142 \\
\hline Market Value of Equity (t-1) & 164401 & 2011.1 & 11439.4 & 13.8 & 41.1 & 170.4 & 810.1 & 3166.4 \\
\hline Book Value of Equity (t-1) & 164401 & 6.2 & 532.3 & 0.7 & 1.1 & 1.7 & 2.9 & 5.1 \\
\hline CAR (\%) & 164401 & -0.4 & 22.7 & -25.4 & -12.6 & -1.1 & 10.5 & 24.8 \\
\hline
\end{tabular}

\begin{tabular}{|l|r|r|r|r|r|r|r|r|r|}
\hline Panel B: Analyst Forecast Earnings SUE-Historical Sales SUE \\
\hline Variable & $\mathbf{N}$ & Mean & $\begin{array}{r}\text { Std } \\
\text { Dev }\end{array}$ & $\begin{array}{r}\text { 10th } \\
\text { Pctl }\end{array}$ & $\begin{array}{r}\text { 25th } \\
\text { Pctl }\end{array}$ & $\begin{array}{r}\text { 50th } \\
\text { Pctl }\end{array}$ & $\begin{array}{r}\text { 75th } \\
\text { Pctl }\end{array}$ & $\begin{array}{r}\text { 90th } \\
\text { Pctl }\end{array}$ \\
\hline Earnings SUE & 65377 & -0.229 & 3.263 & -2.006 & -0.677 & 0.038 & 0.677 & 1.717 \\
\hline Sales SUS & 65377 & 0.179 & 2.088 & -1.756 & -0.825 & 0.069 & 1.069 & 2.168 \\
\hline Proportion of Institutional Holdings & 64956 & 0.519 & 0.204 & 0.234 & 0.368 & 0.532 & 0.674 & 0.779 \\
\hline Arbitrage Risk & 57945 & 0.818 & 0.147 & 0.601 & 0.733 & 0.854 & 0.936 & 0.979 \\
\hline $\begin{array}{l}\text { Average Trading Volume (\% of Outstanding } \\
\text { Shares) }\end{array}$ & 57945 & 0.080 & 0.072 & 0.022 & 0.035 & 0.059 & 0.099 & 0.166 \\
\hline Market Value of Equity (t-1) & 65377 & 4482.9 & 17602.7 & 117.7 & 291.5 & 864.4 & 2748.7 & 8178.0 \\
\hline Book Value of Equity (t-1) & 65377 & 4.0 & 65.4 & 1.1 & 1.5 & 2.2 & 3.5 & 5.9 \\
\hline CAR (\%) & 65377 & -0.7 & 20.7 & -24.4 & -11.5 & -0.4 & 10.2 & 22.5 \\
\hline
\end{tabular}

\begin{tabular}{|l|r|r|r|r|r|r|r|r|}
\hline Panel C: Analyst Forecast Earnings and Sales SUE \\
\hline Variable & $\mathbf{N}$ & Mean & $\begin{array}{r}\text { Std } \\
\text { Dev }\end{array}$ & $\begin{array}{r}\text { 10th } \\
\text { Pctl }\end{array}$ & $\begin{array}{r}\text { 25th } \\
\text { Pctl }\end{array}$ & $\begin{array}{r}\text { 50th } \\
\text { Pctl }\end{array}$ & $\begin{array}{r}\text { 75th } \\
\text { Pctl }\end{array}$ & $\begin{array}{r}\text { 90th } \\
\text { Pctl }\end{array}$ \\
\hline Earnings SUE & 9132 & -0.273 & 3.669 & -2.230 & -0.817 & 0.031 & 0.708 & 1.763 \\
\hline Sales SUS & 9132 & 0.009 & 1.892 & -2.066 & -1.053 & -0.114 & 0.948 & 2.124 \\
\hline Proportion of Institutional Holdings & 9048 & 0.617 & 0.199 & 0.333 & 0.490 & 0.645 & 0.769 & 0.851 \\
\hline Arbitrage Risk & 7860 & 0.858 & 0.106 & 0.710 & 0.795 & 0.879 & 0.940 & 0.977 \\
\hline $\begin{array}{l}\text { Average Trading Volume (\% of Outstanding } \\
\text { Shares) }\end{array}$ & 7860 & 0.128 & 0.096 & 0.038 & 0.061 & 0.101 & 0.166 & 0.258 \\
\hline Market Value of Equity (t-1) & 9132 & 9727.1 & 31391.2 & 201.5 & 489.1 & 1451.4 & 5351.1 & 18403.6 \\
\hline Book Value of Equity (t-1) & 9132 & 4.6 & 7.0 & 1.2 & 1.8 & 2.9 & 5.1 & 8.9 \\
\hline CAR (\%) & 9132 & 0.8 & 26.3 & -30.7 & -13.2 & 1.5 & 15.7 & 30.8 \\
\hline
\end{tabular}

Notes:

1. Panel A includes all firm-quarters. Both earnings and sales SUE are calculated from the

Compustat quarterly database. Earnings (sales) SUE (SUS) is actual earnings (sales) minus 
expected earnings (sales) from a seasonal random walk model with a drift, scaled by the standard deviation of the forecast errors of the seasonal random walk model. SUE (SUS) is estimated for each quarter $\mathrm{t}$, using all observations in quarters $\mathrm{t}-21$ through $\mathrm{t}-1$.

2. Panel $B$ includes all firm-quarters where the earnings SUE is calculated from $I / B / E / S$ as the actual $\mathrm{I} / \mathrm{B} / \mathrm{E} / \mathrm{S}$ EPS minus the mean analyst forecast during the 90 -day period before the disclosure of earnings, scaled by the dispersion of analyst forecasts. Earnings SUE is calculated only if at least two analysts provide earnings forecasts for the firm. The sales SUS is calculated from the Compustat quarterly database and is equal to actual sales minus expected sales from a seasonal random walk model with a drift, scaled by the standard deviation of the forecast errors of the seasonal random walk model. The sales SUS is estimated for each quarter $t$ using all observations in quarters $\mathrm{t}-21$ through $\mathrm{t}-1$.

3. Panel $\mathrm{C}$ includes all firm-quarters where the earnings SUE is calculated from $\mathrm{I} / \mathrm{B} / \mathrm{E} / \mathrm{S}$ as the actual $\mathrm{I} / \mathrm{B} / \mathrm{E} / \mathrm{S}$ EPS minus the mean analyst forecast during the 90 -day period before the disclosure of earnings, scaled by the dispersion of analyst forecasts. Earnings SUE is calculated only if at least two analysts provide earnings forecasts for the firm. Sales SUE is also calculated from $\mathrm{I} / \mathrm{B} / \mathrm{E} / \mathrm{S}$ as the actual $\mathrm{I} / \mathrm{B} / \mathrm{E} / \mathrm{S}$ sales minus the mean forecast of sales during the 90 -day period before the disclosure of earnings, scaled by the actual I/B/E/S sales. The sales SUE is calculated even if only one analyst provided a sales forecast.

4. The proportion of institutional holdings as of the previous quarter's end is obtained by summing all shares held by managers, as reported in 13-f filings with the SEC, and dividing by total shares outstanding as of the end of the previous quarter.

5. Arbitrage risk is one minus the squared correlation between the 60 monthly returns on the stock and those on the S\&P 500 Index, ending one month before the quarter-end.

6. Trading volume is the average monthly number of shares traded during the 60 months ending one month before the quarter-end, divided by the number of shares outstanding at the end of the previous quarter.

7. Market (book) value of equity is as of the end of the previous quarter and is based on Compustat data.

8. CAR is the abnormal return on a stock, cumulated from one day after an earnings announcement through the day of the next quarterly earnings announcement. The abnormal return is the raw return minus the average return on a same size-B/M portfolio (six portfolios), as provided by Professor French. 
Table 2

Regression Results-CAR on Earnings and Sales Surprises

\begin{tabular}{|c|c|c|c|c|c|c|c|c|c|}
\hline \multicolumn{10}{|l|}{ Panel A: Historical SUE and SUS } \\
\hline & Intercept & $\begin{array}{r}\text { DSUE } \\
\text { Earnings } \\
\end{array}$ & $\begin{array}{c}\text { DSUS } \\
\text { Sales } \\
\end{array}$ & $\begin{array}{l}\text { Institnl. } \\
\text { Holding }\end{array}$ & $\begin{array}{r}\text { Arbitrg. } \\
\text { Risk } \\
\end{array}$ & $\begin{array}{l}\text { Trading } \\
\text { Volume } \\
\end{array}$ & $\mathbf{N}$ & R-Sqr. & Signf. \\
\hline Expected sign & & + & + & - & + & - & & & \\
\hline Earnings only & -2.933 & 5.640 & & & & & 164400 & 0.005 & 0.001 \\
\hline Significance (t-stat) & 0.001 & 0.001 & & & & & & & \\
\hline Earnings only (F-M) & -3.058 & 5.422 & & & & & & & \\
\hline Significance (F-M t-stat) & 0.001 & 0.001 & & & & & & & \\
\hline Earnings and sales & -2.833 & 4.177 & 2.386 & & & & 164400 & 0.005 & 0.001 \\
\hline Significance (t-stat) & 0.001 & 0.001 & 0.001 & & & & & & \\
\hline Earnings and sales (F-M) & -2.938 & 3.643 & 2.918 & & & & & & \\
\hline Significance (F-M t-stat) & 0.001 & 0.001 & 0.001 & & & & & & \\
\hline Earnings, Sales and Controls & -2.887 & 7.642 & 2.965 & -0.725 & 0.056 & -0.893 & 142420 & 0.008 & 0.001 \\
\hline Significance (t-stat) & 0.001 & 0.001 & 0.001 & 0.001 & 0.006 & 0.006 & & & \\
\hline Earnings, Sales and Controls (F-M) & -3.104 & 7.855 & 3.128 & -0.728 & 0.067 & -1.714 & & & \\
\hline Significance (F-M t-stat) & 0.001 & 0.001 & 0.001 & 0.001 & 0.232 & 0.016 & & & \\
\hline \multicolumn{10}{|c|}{ Panel B: Analyst Forecast Earnings and Sales Surprises } \\
\hline Earnings only & -1.569 & 5.019 & & & & & 9131 & 0.003 & 0.001 \\
\hline Significance (t-stat) & 0.004 & 0.001 & & & & & & & \\
\hline Earnings only (F-M) & -0.131 & 4.633 & & & & & & & \\
\hline Significance (F-M t-stat) & 0.936 & 0.026 & & & & & & & \\
\hline Earnings and sales & -1.399 & 2.513 & 4.483 & & & & 9131 & 0.003 & 0.001 \\
\hline Significance (t-stat) & 0.011 & 0.092 & 0.024 & & & & & & \\
\hline Earnings and sales (F-M) & 0.205 & -0.053 & 8.316 & & & & & & \\
\hline Significance (F-M t-stat) & 0.898 & 0.983 & 0.044 & & & & & & \\
\hline Earnings, Sales and Controls & -0.897 & -1.722 & 3.913 & 0.445 & 0.126 & 0.025 & 7788 & 0.003 & 0.001 \\
\hline Significance (t-stat) & 0.122 & 0.579 & 0.057 & 0.207 & 0.518 & 0.982 & & & \\
\hline Earnings, Sales and Controls (F-M) & 0.104 & -5.250 & 7.631 & 0.684 & 0.449 & -3.621 & & & \\
\hline Significance (F-M t-stat) & 0.947 & 0.370 & 0.073 & 0.239 & 0.190 & 0.341 & & & \\
\hline
\end{tabular}

Notes:

1. Panel A includes all firm-quarters where both earnings and sales surprises are calculated from the Compustat quarterly database. Earnings (sales) SUE (SUS) is actual earnings (sales) minus expected earnings (sales) from a seasonal random walk model with a drift, scaled by the standard deviation of the forecast errors of the seasonal random walk model. SUE (SUS) is estimated for each quarter $\mathrm{t}$, using all observations in quarters $\mathrm{t}-21$ through $\mathrm{t}-1$.

2. Panel $B$ includes all firm-quarters where the earnings SUE is calculated from $I / B / E / S$ as the actual $\mathrm{I} / \mathrm{B} / \mathrm{E} / \mathrm{S}$ EPS minus the mean analyst forecast during the 90-day period before the disclosure of earnings, scaled by the dispersion of analyst forecasts. Earnings SUE is calculated only if at least two analysts provide earnings forecasts for the firm. Sales SUS is also calculated from $\mathrm{I} / \mathrm{B} / \mathrm{E} / \mathrm{S}$ as the actual $\mathrm{I} / \mathrm{B} / \mathrm{E} / \mathrm{S}$ sales minus the mean forecast of sales during the 90 -day period before the disclosure of earnings, scaled by the actual I/B/E/S sales. The sales SUS is calculated even if only one analyst provided a sales forecast.

3. Earnings (sales) DSUE (DSUS) is the decile rank of the earnings (sales) SUE (SUS), scaled to fall between zero and one. The table entries for DSUS represent the interaction between DSUE and DSUS. 
4. The proportion of institutional investors is obtained by summing all shares held by managers, as reported in 13-f filings with the SEC, and dividing by total shares outstanding at the end of the previous quarter. It is assigned its decile rank and interacted with the earnings DSUE.

5. Arbitrage risk is one minus the squared correlation between the 60 monthly returns on the stock and those on the S\&P 500 Index, ending one month before the quarter-end. It is interacted with SUE.

6. Trading volume is the average monthly number of shares traded during the 60 months ending one month before the quarter-end, divided by the number of shares outstanding at the end of the previous quarter. It is interacted with SUE.

7. CAR is the abnormal return on a stock, cumulated from one day after an earnings announcement for quarter $t$ through the day of the earnings announcement for quarter $t+1$. The abnormal return is the raw return minus the average return on a same size-B/M portfolio (six portfolios), as provided by Professor French.

8. The table reports results of a pooled firm-quarter regressions, as well as quarter-by-quarter regressions summarized according to the methodology of Fama and MacBeth (1973), denoted by F-M in the table.

9. Bold figures represent entries that are statistically different from zero at the $10 \%$ significance level or better. 


\section{Table 3}

\section{Distribution of Abnormal Returns-SUE (SUS) Groups}

\begin{tabular}{|c|c|c|c|c|c|c|}
\hline \multicolumn{2}{|c|}{$\begin{array}{l}\text { Panel A: Historical SUE } \\
\text { and SUS }\end{array}$} & \multicolumn{5}{|c|}{ DSUS } \\
\hline \multirow{13}{*}{ DSUE } & & & $\begin{array}{r}\text { Bottom } \\
\mathbf{3 0 \%} \\
\end{array}$ & $\begin{array}{r}\text { Middle } \\
\mathbf{4 0 \%} \\
\end{array}$ & Top 30\% & Total \\
\hline & \multirow{3}{*}{ Bottom 30\% } & CAR (\%) & -2.38 & -2.32 & -2.01 & -2.30 \\
\hline & & & 25254 & 16796 & 7892 & 49942 \\
\hline & & Significance & 0.001 & 0.001 & 0.001 & 0.001 \\
\hline & \multirow{3}{*}{ Middle 40\% } & CAR (\%) & -1.13 & -0.41 & -0.05 & -0.49 \\
\hline & & & 16232 & 30361 & 17886 & 64479 \\
\hline & & Significance & 0.001 & 0.001 & 0.766 & 0.001 \\
\hline & \multirow{3}{*}{ Top 30\% } & CAR (\%) & 0.57 & 1.52 & 2.07 & 1.64 \\
\hline & & & 7903 & 17824 & 24253 & 49980 \\
\hline & & Significance & 0.029 & 0.001 & 0.001 & 0.001 \\
\hline & \multirow{3}{*}{ Total } & CAR (\%) & -1.50 & -0.37 & 0.67 & -0.39 \\
\hline & & & 49389 & 64981 & 50031 & 164401 \\
\hline & & Significance & 0.001 & 0.001 & 0.001 & 0.001 \\
\hline \multirow{2}{*}{\multicolumn{7}{|c|}{$\begin{array}{l}\text { Panel B: Analyst } \\
\text { Forecast Earnings and } \\
\text { Sales Surprises }\end{array}$}} \\
\hline & & & & & & \\
\hline \multirow{13}{*}{ DSUE } & & & $\begin{array}{r}\text { Bottom } \\
\mathbf{3 0 \%}\end{array}$ & $\begin{array}{r}\text { Middle } \\
40 \% \\
\end{array}$ & Top 30\% & Total \\
\hline & & CAR (\%) & -1.67 & 0.15 & 2.95 & -0.25 \\
\hline & Bottom 30\% & $\mathbf{N}$ & 1050 & 897 & 355 & 2302 \\
\hline & & Significance & 0.062 & 0.867 & 0.063 & 0.669 \\
\hline & \multirow{3}{*}{ Middle 40\% } & CAR (\%) & -0.03 & -0.57 & 0.20 & -0.25 \\
\hline & & $\mathbf{N}$ & 1114 & 1972 & 880 & 3966 \\
\hline & & Significance & 0.967 & 0.312 & 0.805 & 0.531 \\
\hline & \multirow{3}{*}{ Top 30\% } & CAR (\%) & 2.10 & 2.41 & 4.48 & 3.11 \\
\hline & & $\mathbf{N}$ & 496 & 1326 & 1042 & 2864 \\
\hline & & Significance & 0.067 & 0.001 & 0.001 & 0.001 \\
\hline & \multirow{3}{*}{ Total } & CAR (\%) & -0.28 & 0.53 & 2.59 & 0.80 \\
\hline & & $\mathbf{N}$ & 2660 & 4195 & 2277 & 9132 \\
\hline & & Significance & 0.587 & 0.187 & 0.001 & 0.003 \\
\hline
\end{tabular}

\section{Notes:}

1. Panel A includes all firm-quarters where earnings (sales) SUE (SUS) is calculated from the Compustat quarterly database. Earnings (sales) SUE (SUS) is actual earnings (sales) minus expected earnings (sales) from a seasonal random walk model with a drift, scaled by the standard 
deviation of the forecast errors of the seasonal random walk model. SUE (SUS) is estimated for each quarter $\mathrm{t}$, using all observations in quarters $\mathrm{t}-21$ through $\mathrm{t}-1$.

2. Panel $B$ includes all firm-quarters where the earnings SUE is calculated from $\mathrm{I} / \mathrm{B} / \mathrm{E} / \mathrm{S}$ as the actual $\mathrm{I} / \mathrm{B} / \mathrm{E} / \mathrm{S}$ EPS minus the mean analyst forecast during the 90-day period before the disclosure of earnings, scaled by the dispersion of analyst forecasts. Earnings SUE is calculated only if at least two analysts provide earnings forecasts for the firm. Sales SUS is also calculated from I/B/E/S as the actual I/B/E/S sales minus the mean forecast of sales during the 90 -day period before the disclosure of earnings, scaled by the actual I/B/E/S sales. The sales surprise SUS is calculated even if only one analyst provided a sales forecast.

3. CAR is the abnormal return on a stock, cumulated from one day after an earnings announcement for quarter $t$ through the day of the earnings announcement for quarter $t+1$. The abnormal return is the raw return minus the average return on a same size-B/M portfolio (six portfolios), as provided by Professor French.

4. The table presents results for firms that fall into one of nine groups classified according to an earnings surprise (SUE) and sales surprise (SUS). For each variable, firms are assigned (independently) into a bottom $30 \%$ group, a middle $40 \%$ group, or a top $30 \%$ group.

5. N shows the number of firms in a particular cell. 


\section{Table 4 \\ Hedge Portfolio Returns}

\begin{tabular}{|c|c|c|c|}
\hline & $\begin{array}{l}\text { Earnings- } \\
\text { Based } \\
\text { Hedge } \\
\text { Portfolio } \\
\quad \text { (1) }\end{array}$ & $\begin{array}{l}\text { Earnings- } \\
\text { and } \\
\text { Sales-Based } \\
\text { Hedge } \\
\text { Portfolio } \\
\quad \text { (2) }\end{array}$ & $\begin{array}{c}\text { Difference } \\
(2-1)\end{array}$ \\
\hline \multicolumn{4}{|l|}{ Panel A: Historical SUE and SUS (63 quarters) } \\
\hline $\mathrm{CAR}(\%)$ & 1.944 & 2.210 & 0.266 \\
\hline Standard Deviation of CAR & 1.159 & 1.833 & 0.917 \\
\hline t-statistic & 13.31 & 9.57 & 2.3 \\
\hline Significance level & 0.001 & 0.001 & 0.025 \\
\hline Average number of firms & 1586 & 786 & \\
\hline \multicolumn{4}{|l|}{$\begin{array}{l}\text { Panel B: Analyst Forecast SUE and SUS (17 } \\
\text { quarters) }\end{array}$} \\
\hline CAR $(\%)$ & 2.199 & 3.620 & 1.421 \\
\hline Standard Deviation of CAR & 3.331 & 4.611 & 2.620 \\
\hline t-statistic & 2.72 & 3.24 & 2.24 \\
\hline Significance level & 0.015 & 0.005 & 0.040 \\
\hline Average number of firms & 302 & 122 & \\
\hline
\end{tabular}

\section{Notes:}

1. Panel A includes all firm-quarters where earnings (sales) SUE (SUS) is calculated from the Compustat quarterly database. Earnings (sales) SUE (SUS) is actual earnings (sales) minus expected earnings (sales) from a seasonal random walk model with a drift, scaled by the standard deviation of the forecast errors of the seasonal random walk model. SUE (SUS) is estimated for each quarter $\mathrm{t}$, using all observations in quarters $\mathrm{t}-21$ through $\mathrm{t}-1$.

2. Panel $B$ includes all firm-quarters where the earnings SUE is calculated from $I / B / E / S$ as the actual $\mathrm{I} / \mathrm{B} / \mathrm{E} / \mathrm{S}$ EPS minus the mean analyst forecast during the 90 -day period before the disclosure of earnings, scaled by the dispersion of analyst forecasts. Earnings SUE is calculated only if at least two analysts provide earnings forecasts for the firm. Sales SUS is also calculated from I/B/E/S as the actual $\mathrm{I} / \mathrm{B} / \mathrm{E} / \mathrm{S}$ sales minus the mean forecast of sales during the 90 -day period before the disclosure of earnings, scaled by the actual I/B/E/S sales. The sales surprise SUS is calculated even if only one analyst provided a sales forecast.

3. CAR is the abnormal return on a stock, cumulated from one day after an earnings announcement for quarter $t$ through the day of the earnings announcement for quarter $t+1$. The abnormal return is the raw return minus the average return on a same size-B/M portfolio (six portfolios), as provided by Professor French.

4. The hedge portfolio assumes long positions in the top 30\% and short positions in the bottom $30 \%$ of firms sorted according to SUE, in column (1), and both SUE and SUS, in column (2).

5. Bold figures represent entries that are statistically different from zero at the $5 \%$ significance level or better. 


\section{Table 5}

\section{Regression Results-CAR on Earnings and Sales Surprises Various Sub-Periods}

\begin{tabular}{|c|c|c|c|c|c|c|c|c|c|}
\hline \multicolumn{10}{|l|}{ Observations Before 1993} \\
\hline & Intercept & $\begin{array}{r}\text { DSUE } \\
\text { Earnings } \\
\end{array}$ & $\begin{array}{l}\text { DSUS } \\
\text { Sales } \\
\end{array}$ & $\begin{array}{l}\text { Institnl. } \\
\text { Holding }\end{array}$ & $\begin{array}{r}\text { Arbitrg. } \\
\text { Risk } \\
\end{array}$ & $\begin{array}{l}\text { Trading } \\
\text { Volume }\end{array}$ & $\mathbf{N}$ & $\begin{array}{r}\text { R- } \\
\text { Sqr. }\end{array}$ & Signf. \\
\hline Expected sign & & + & + & - & + & - & & & \\
\hline $\begin{array}{l}\text { Earnings only } \\
\text { Significance (t-stat) }\end{array}$ & $\begin{array}{r}-3.448 \\
0.001 \\
\end{array}$ & $\begin{array}{l}6.546 \\
0.001 \\
\end{array}$ & & & & & 44521 & 0.009 & 0.001 \\
\hline $\begin{array}{l}\text { Earnings and sales } \\
\text { Significance (t-stat) }\end{array}$ & $\begin{array}{r}-3.319 \\
0.001 \\
\end{array}$ & $\begin{array}{l}4.575 \\
0.001\end{array}$ & $\begin{array}{l}3.233 \\
0.001\end{array}$ & & & & 44521 & 0.010 & 0.001 \\
\hline $\begin{array}{l}\text { Earnings, Sales and Controls } \\
\text { Significance (t-stat) }\end{array}$ & $\begin{array}{r}-3.417 \\
0.001 \\
\end{array}$ & $\begin{array}{l}9.445 \\
0.001\end{array}$ & $\begin{array}{l}3.367 \\
0.001\end{array}$ & $\begin{array}{r}-0.914 \\
0.001 \\
\end{array}$ & $\begin{array}{r}0.003 \\
0970 \\
\end{array}$ & $\begin{array}{r}-0.107 \\
0.882 \\
\end{array}$ & 39725 & 0.014 & 0.001 \\
\hline \multicolumn{10}{|l|}{ Observations in 1993-1997 } \\
\hline $\begin{array}{l}\text { Earnings only } \\
\text { Significance (t-stat) }\end{array}$ & $\begin{array}{r}-3.442 \\
0.001 \\
\end{array}$ & $\begin{array}{l}4.859 \\
0.001\end{array}$ & & & & & 50670 & 0.006 & 0.001 \\
\hline $\begin{array}{l}\text { Earnings and sales } \\
\text { Significance (t-stat) }\end{array}$ & $\begin{array}{r}-3.319 \\
0.001 \\
\end{array}$ & $\begin{array}{l}3.159 \\
0.001\end{array}$ & $\begin{array}{l}2.714 \\
0.001\end{array}$ & & & & 50670 & 0.006 & 0.001 \\
\hline $\begin{array}{l}\text { Earnings, Sales and Controls } \\
\text { Significance (t-stat) }\end{array}$ & $\begin{array}{r}-3.507 \\
0.001 \\
\end{array}$ & $\begin{array}{l}5.749 \\
0.001\end{array}$ & $\begin{array}{l}3.371 \\
0.001\end{array}$ & $\begin{array}{r}-0.512 \\
0.001 \\
\end{array}$ & $\begin{array}{l}0.034 \\
0.555\end{array}$ & $\begin{array}{r}-1.644 \\
0.001 \\
\end{array}$ & 44392 & 0.008 & 0.001 \\
\hline \multicolumn{10}{|l|}{ Observations in 1998-2002 } \\
\hline $\begin{array}{l}\text { Earnings only } \\
\text { Significance (t-stat) }\end{array}$ & $\begin{array}{r}-2.248 \\
0.001 \\
\end{array}$ & $\begin{array}{l}5.681 \\
0.001\end{array}$ & & & & & 69207 & 0.004 & 0.001 \\
\hline $\begin{array}{l}\text { Earnings and sales } \\
\text { Significance (t-stat) }\end{array}$ & $\begin{array}{r}-2.176 \\
0.001 \\
\end{array}$ & $\begin{array}{l}4.596 \\
0.001\end{array}$ & $\begin{array}{l}1.790 \\
0.010\end{array}$ & & & & 69207 & 0.004 & 0.001 \\
\hline $\begin{array}{l}\text { Earnings, Sales and Controls } \\
\text { Significance (t-stat) }\end{array}$ & $\begin{array}{r}-2.164 \\
0.001 \\
\end{array}$ & $\begin{array}{l}8.025 \\
0.001\end{array}$ & $\begin{array}{l}2.467 \\
0.004\end{array}$ & $\begin{array}{r}-0.750 \\
0.001 \\
\end{array}$ & $\begin{array}{l}0.034 \\
0.318\end{array}$ & $\begin{array}{r}-0.524 \\
0.328 \\
\end{array}$ & 58301 & 0.005 & 0.001 \\
\hline
\end{tabular}

Notes:

1. Earnings (sales) DSUE (DSUS) is the decile rank of the earnings (sales) SUE (SUS), scaled to fall between zero and one. The DSUS is interacted with DSUE in the regressions that contain both terms.

2. The proportion of institutional investors is obtained by summing all shares held by managers, as reported in 13-f filings with the SEC, and dividing by total shares outstanding at the end of the previous quarter. It is assigned its decile rank and interacted with the earnings DSUE.

3. Arbitrage risk is one minus the squared correlation between the 60 monthly returns on the stock and those on the S\&P 500 Index, ending one month before the quarter-end. It is interacted with the earnings DSUE.

4. Trading volume is the average monthly number of shares traded during the 60 months ending one month before the quarter-end, divided by the number of shares outstanding at the end of the previous quarter. It is interacted with the earnings DSUE.

5. CAR is the abnormal return on a stock, cumulated from one day after an earnings announcement for quarter $t$ through the day of the earnings announcement for quarter $t+1$. The abnormal return is the raw return minus the average return on a same size-B/M portfolio (six portfolios), as provided by Professor French.

6. The table reports results of a pooled firm-quarter regression.

7. Bold figures represent entries that are statistically different from zero at the $5 \%$ significance level or better. 


\section{Table 6 \\ Regression Results-CAR on Earnings and Earnings \\ Persistence}

\begin{tabular}{|c|c|c|c|c|c|c|c|c|c|}
\hline \multicolumn{10}{|l|}{ Panel A: Historical SUE } \\
\hline & Intercept & $\begin{array}{r}\text { DSUE } \\
\text { Earnings } \\
\end{array}$ & $\begin{array}{r}\text { Earnings } \\
\text { Persistence } \\
\end{array}$ & $\begin{array}{l}\text { Institnl. } \\
\text { Holding }\end{array}$ & $\begin{array}{r}\text { Arbitrg. } \\
\text { Risk } \\
\end{array}$ & $\begin{array}{l}\text { Trading } \\
\text { Volume } \\
\end{array}$ & $\mathbf{N}$ & R-Sqr. & Signf. \\
\hline Expected sign & & + & + & - & + & - & & & \\
\hline Earnings and persistence & -2.972 & 4.532 & 3.675 & & & & 152086 & 0.006 & 0.001 \\
\hline Significance (t-stat) & 0.001 & 0.001 & 0.001 & & & & & & \\
\hline Earnings, persistence and controls & -3.062 & 8.546 & 3.349 & -0.720 & 0.059 & -0.943 & 136279 & 0.008 & 0.001 \\
\hline Significance (t-stat) & 0.001 & 0.001 & 0.001 & 0.001 & 0.005 & 0.005 & & & \\
\hline \multicolumn{10}{|l|}{ Panel B: Analyst Forecast Earnings } \\
\hline Earnings and persistence & -4.043 & 6.943 & 1.742 & & & & 62182 & 0.011 & 0.001 \\
\hline Significance (t-stat) & 0.001 & 0.01 & 0.004 & & & & & & \\
\hline Earnings, persistence and controls & -3.627 & 5.691 & .928 & 0.067 & 0.004 & 0.826 & 56344 & 0.011 & 0.001 \\
\hline Significance (t-stat) & 0.001 & 0.001 & 0.138 & 0.461 & 0.842 & 0.001 & & & \\
\hline
\end{tabular}

Notes:

1. Panel A includes all firm-quarters where the earnings surprise is calculated from the Compustat quarterly database. Earnings SUE is actual earnings minus expected earnings from a seasonal random walk model with a drift, scaled by the standard deviation of the forecast errors of the seasonal random walk model. SUE is estimated for each quarter $t$, using all observations in quarters $\mathrm{t}-21$ through $\mathrm{t}-1$.

2. Panel $B$ includes all firm-quarters where the earnings SUE is calculated from $\mathrm{I} / \mathrm{B} / \mathrm{E} / \mathrm{S}$ as the actual $\mathrm{I} / \mathrm{B} / \mathrm{E} / \mathrm{S}$ EPS minus the mean analyst forecast during the 90 -day period before the disclosure of earnings, scaled by the dispersion of analyst forecasts. Earnings SUE is calculated only if at least two analysts provide earnings forecasts for the firm.

3. Earnings DSUE is the decile rank of the earnings SUE, scaled to fall between zero and one. The table entries for persistence represent the interaction between DSUE and persistence. Persistence is measured as the first auto-correlation in earnings surprises (SUE) over all available quarterly observations for a firm, with a minimum of 9 observations.

4. The proportion of institutional investors is obtained by summing all shares held by managers, as reported in 13-f filings with the SEC, and dividing by total shares outstanding at the end of the previous quarter. It is assigned its decile rank and interacted with the earnings DSUE.

5. Arbitrage risk is one minus the squared correlation between the 60 monthly returns on the stock and those on the S\&P 500 Index, ending one month before the quarter-end. It is interacted with SUE.

6. Trading volume is the average monthly number of shares traded during the 60 months ending one month before the quarter-end, divided by the number of shares outstanding at the end of the previous quarter. It is interacted with SUE.

7. CAR is the abnormal return on a stock, cumulated from one day after an earnings announcement for quarter $t$ through the day of the earnings announcement for quarter $t+1$. The abnormal return is the raw return minus the average return on a same size-B/M portfolio (six portfolios), as provided by Professor French.

10. Bold figures represent entries that are statistically different from zero at the $10 \%$ significance level or better. 